УДК 621.129

\title{
ОСВІТЛЕННЯ ВОДИ КОАГУЛАНТАМИ І ФЛОКУЛАНТАМИ У СИСТЕМАХ ОБОРОТНОГО ВОДОПОСТАЧАННЯ КОКСОВОГО ЗАВОДУ
}

\author{
О.П. Галкіна ${ }^{1}$, С.О. Куницький \\ ${ }^{1}$ Харківський національний університет міського господарства імені О. М. Бекетова \\ вул. Маршала Бажанова, 17, Харків, 61002, Україна \\ e-mail: helen.smilka31@gmail.com \\ ${ }^{2}$ Національний університет водного господарства та природокористування \\ вул. Соборна, 11, Рівне, 33028, Україна \\ e-mail: s.o.kunytskiy@nuwm.edu.ua
}

Проблема очищення стічних вод коксохімічного виробництва вирішується комплексом фізико-хімічних, механічних і біохімічних методів, які використовуються для очищення локальних стоків і загального фенольного стоку на біохімічних установках. Вибір методів і ефективність очищення багато в чому визначаються тим, як використовуються очищені стічні води. На більшості діючих коксохімічних підприємств очищені стічні води використовуються для гасіння коксу [1-3].

Зарубіжний досвід очищення фенольних стічних вод на коксохімічних підприємствах показує, що очищення проводиться екстракційним методом, а їхнє доочищення - біологічним. На деяких заводах встановлені кварцові фільтри, які ефективно витягують смолисті речовини 3 надсмольної води, і флотаційні установки для знемаслення стічних вод, а також біологічні установки для знешкодження стічних вод. Останнім часом актуальним є доочищення стічних вод, адже лише однієї біохімічного очищення промислових стічних вод у ряді випадків уже недостатньо [1-4].

Стічні води коксохімічних підприємств в залежності від характеру i концентрації забруднень, що містяться в ній, а також від напрямку використання цих вод, потребують різної підготовки [1-3].

Зазвичай підготовку фенольних стічних вод проводять у наступному порядку:

- очищення від механічних домішок, смол і масел у відстійниках;

- біохімічне очищення від фенолів, аміаку, роданідів і ціанідів в аеротенках;

- доочищення на фільтрах із зернистим завантаженням;

- стабілізаційне оброблення речовинами - інгібіторами корозії й інгібіторами утворення щільних сольових відкладень.

Основним недоліком замкнених систем є необхідність в продувці системи і заповненні системи свіжою водою. Однак існуючі методи інтенсифікації очищення води на коксохімічних підприємствах при використанні фенольних стічних вод у якості підживлення системи не завжди прийнятні, оскільки вони приводять до збільшення вмісту завислих речовин, біообростанню та ін. Тому є необхідність видалення завислих речовин реагентною обробкою води фізико-хімічними i біологічними методами очищення води на коксохімічних підприємствах з подальшим доочищенням. Аналіз методів очищення фенольних стічних вод 
та досвід роботи коксохімічних підприємств показав необхідність інтенсифікації процесу очищення води при застосуванні ефективних коагулянтів флокулянтів та необхідність доочищення води фільтрацією.

Таким чином, $є$ актуальним розробка і обгрунтування інтенсифікації процесу очищення води для доведення iї якості для повторного використання в оборотних системах водопостачання коксохімічних підприємств при застосуванні ефективних реагентів.

Метою даного дослідження є обгрунтування методу очищення води на коксохімічних підприємствах із використанням ефективних коагулянтів і флокулянтів для доведення якості оборотної води для повторного використання в системі.

Експериментальні дослідження проводились на Харківському коксохімічному заводі. Кількість завислих частинок на ПрАТ «Харківський коксовий завод» коливається в межах 500$600 \mathrm{мг} /$ дм $^{3}$ - це вказує на те, що в оборотній воді відбувається процес життєдіяльності мікроорганізмів, а також винесення шлаків з БХУ і коксового цеху.

Пропонується використовувати один із способів підготовки води видалення завислих речовин - метод коагуляції шляхом оброблення сучасними ефективними коагулянтами $\mathrm{i}$ флокулянтами.

На коксохімічних заводах реагенти в основному застосовують для локального очищення стічних вод окремих цехів від завислих речовин, смол і масел. Використання залізного купоросу FeSO4 (з дозою 30-70 мг/дм3) на ПрАТ «Харківський коксовий завод» дозволяе зменшити залишковий вміст завислих речовин, смол і масел в два рази в порівнянні 3 безреагентним відстоюванням або флотацією.

Дослідження, що оцінювали ефективність додавання коагулянтів та флокулянтів та визначали ї оптимальну дозу, проводили згідно загальноприйнятого методу пробної коагуляції [1-3].

При дослідженні i виборі сучасних коагулянтів i/або флокулянтів були проведені експерименти. Приготування досліджуваних розчинів коагулянтів (сульфат алюмінію $\mathrm{Al}_{2}\left(\mathrm{SO}_{4}\right)_{3}$, гідроксихлорид алюмінію Pro-AQUA-18) і флокулянтів - Extraflock i Besfloc (Південна Корея, виробництва Kolon Life Science inc i ПХЗ «Коагулянт» Запорізька обл., Україна) проводилися в лабораторних умовах.

Застосування сульфату алюмінію малоефективно, його доза становить 130 мг/дм³ . Наявне оброблення води коагулянтами, наведеними вище, неефективне і суттєво знижує $\mathrm{pH}$ води. Оскільки застосування деяких коагулянтів, особливо у великих дозах, призводить до підкислення стічної води, необхідно додатково проводити коригування $\mathrm{pH}$ лужними реагентами.

Результати досліджень показують доцільність використання коагулянтів Pro-AQUA-18 у дозі $50 \mathrm{мг/дм}{ }^{3}$ та флокулянтів Extraflock у дозі 2-6 мг/дм³ та Besfloc - у дозі 2-4 мг/дм³ окремо та разом з сірчанокислою алюмінієм для очищення води (рис. 1).

Було виявлено, що використання катіонних флокулянтів при обробці води показало високу ефективність у фенольних стічних водах та високе видалення завислих речовин порівняно 3 аніонними та іонними флокулянтами $(E=80-90 \%)$. Загалом, результати досліджень вказують на високу ефективність використання коагулянтів Pro-AQUA-18 та флокулянтів Extraflock, Besfloc при самостійному використанні та спільно з сульфатом алюмінію (рис. 1) [4-5].

Аналіз результатів експериментів показав, що реагентна обробка води шляхом застосування органічних флокулянтів (у дозі 2-4 мг/дм³) для освітлення досліджуваної води не призводить до вторинного забруднення води та зменшує кількість завислих речовин у циркулююча вода (50-100 мг/дм³), що дозволяє інтенсифікувати процес очищення води на коксохімічних заводах. 


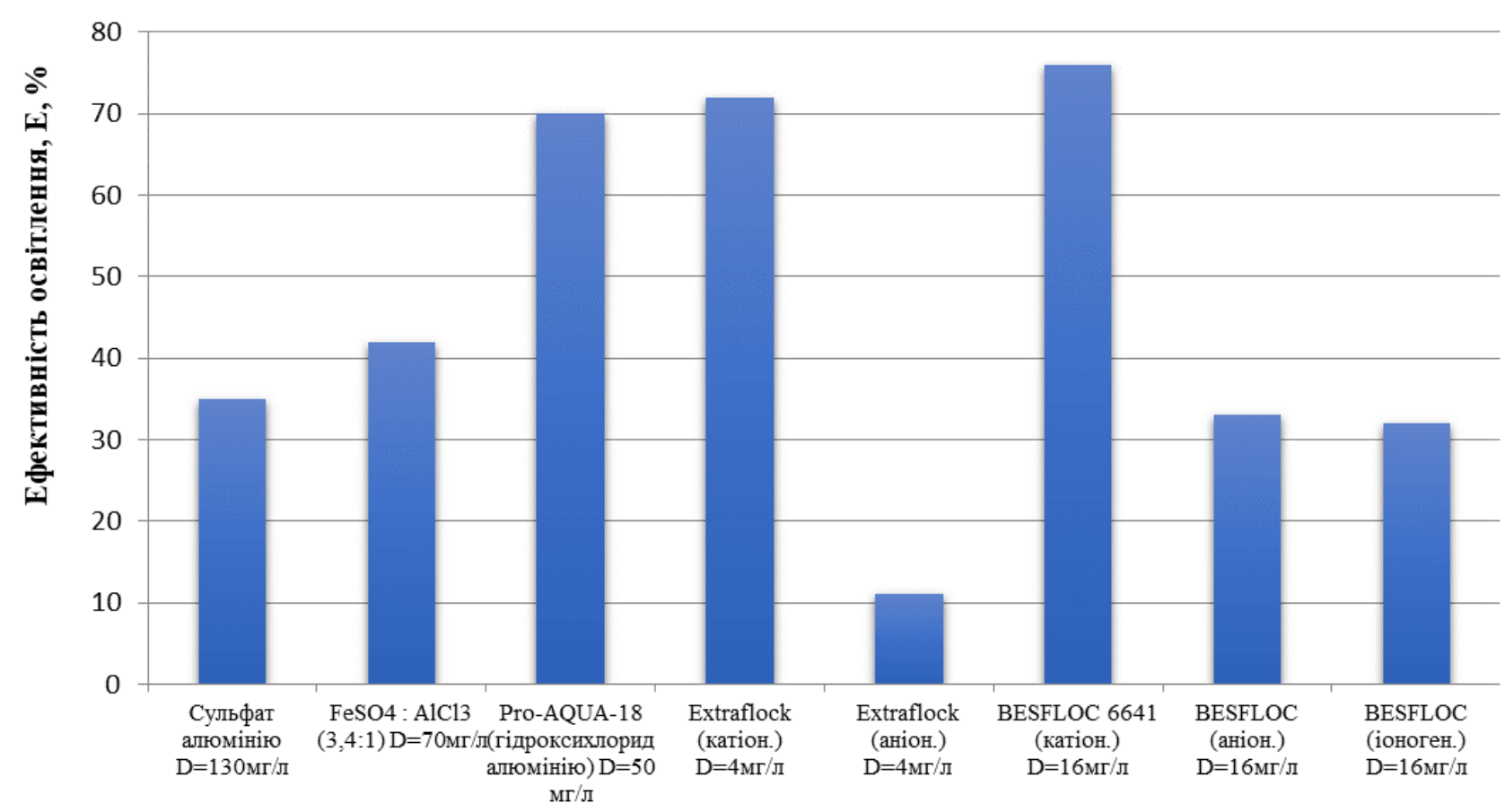

Рисунок. Ефективність різних типів флокулянтів щодо очищення води

\section{Література:}

1. Драгинский В.Л., Алексеева Л.П., Гетьманцев С.В. Коагуляция в технологии очистки воды, Науч. изд. - М., 2005. 576 с.

2. Гетьманцев С.В., Нечаев И.А., Гандурина Л.В. Очистка производственных сточных вод коагулянтами и флокулянтами, М. : Науч. изд-во АСВ, 2008. 272 с.

3. Вейцер Ю.И., Минц Д.М. Высокомолекулярные флокулянты в процесах очистки природных и сточных вод. М.: Стройиздат, 1984. 201 с.

4. Nesterenko, S.V., Tkachev, V.A., \& Smilka, E. P. (2013). Reducing the corrosion losses of metals when using phenolic wastewater in coke-plant cooling systems. Coke and Chemistry, 56(8), 2013, pp. 286-291.

5. Galkina O., H. Blahodarna. The Use of Effective Coagulants and Flocculants to Intensify the Process of Water Purification at Coke Plants. Slovak Journal of Civil Engineering, Vol. 27, 2019, No. 2. pp. $21-28$. 